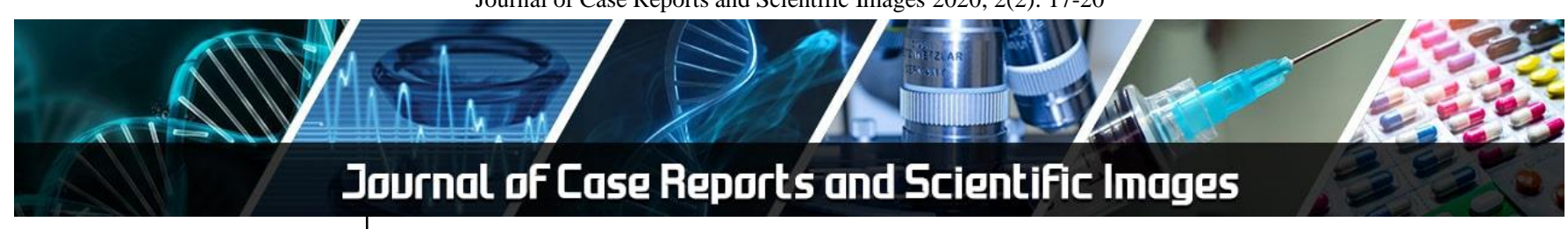

E-ISSN: 2708-0064

P-ISSN: 2708-0056

IJCRS 2020; 2(2): 17-20

http://www.allcasereports.com

Received: 28-04-2020

Accepted: 18-06-2020

Divya V

Sree Mookambika Institute of Medical Sciences, Padanilam, Kulesekharam, Kanyakumari, Tamil Nadu, India

\section{Rajendran N}

Sree Mookambika Institute of Medical Sciences, Padanilam, Kulesekharam, Kanyakumari, Tamil Nadu, India

Kishore Kumar J

Sree Mookambika Institute of Medical Sciences, Padanilam, Kulesekharam, Kanyakumari, Tamil Nadu, India
Corresponding Author: Divya V

Sree Mookambika Institute of Medical Sciences, Padanilam, Kulesekharam, Kanyakumari, Tamil Nadu, India

\section{Prevalence of diabetic retinopathy among type 2 diabetes mellitus in tertiary care centre}

\author{
Divya V, Rajendran N and Kishore Kumar J
}

DOI: https://doi.org/10.22271/27080056.2020.v2.i2a.20

\begin{abstract}
Background: Diabetes mellitus is one of the most insidious disease across the globe. Diabetic retinopathy is recognised as a leading cause of blindness and visual impairment in working-age adults in developed and developing countries.

Objective: To assess the prevalence of diabetic retinopathy among type 2 diabetes mellitus and severity of diabetic retinopathy attending ophthalmology out patient department in sree mookambika institute of medical sciences, Kulesekharam, Kanyakumari.

Material and Method: Cross sectional study among 85 Type 2 diabetes mellitus patients of age more than 40 years, duration more than 5 years. Statistical methods of analysis: Study parameters will be entered in Microsoft Office Excel 2013, Descriptive statistics-Mean and Standard Deviation; Qualitative test-Chi square test using SPSS TRAIL VERSION-20.0.

Result: In my study prevalence of diabetic retinopathy was $55.30 \%$ (47 patients) of which 14.89 $\%$ mild NPDR (7 patients); moderate NPDR 34.05\% (16 patients); Severe NPDR 25.53\% (12 patients); PDR $25.53 \%$ (12 patients).

Conclusion: This study estimated the prevalence of DR in Kulesekharam, Kanyakumari, Hospital based type 2 diabetic population attending ophthalmology out patient department sree mookambiga institute of medical sciences. Our study also created awareness among the patients who participated about diabetic retinopathy.
\end{abstract}

Keywords: Tertiary care centre, diabetic retinopathy, Kulesekharam, Kanyakumari

\section{Introduction}

Diabetes mellitus is one of the most insidious disease across the globe. According to the International Diabetes Federation (IDF) Diabetes Atlas 2017. It was estimated that in 2017 there are 451 million (age 18-99years) people with diabetes mellitus worldwide. These figures were expected to increase to 693 million by $2045^{[1]}$.

India leading the World and standing at the second position after China, with 69 million persons affected by diabetes poses a daunting challenge to the sustainable development of the nation as almost every tenth adult (9.3\%) in India is estimated to be affected by diabetes mellitus ${ }^{[2]}$. Type-2 diabetes mellitus (T2DM) is the predominant form of diabetes worldwide, accounting to $90 \%$ of cases globally ${ }^{[3]}$. According to WHO the figure of people affected by diabetes mellitus is estimated to rise to 79.4 million by $2030^{\text {[4] }}$. Diabetic retinopathy is recognised as a leading cause of blindness and visual impairment in workingage adults in developed and developing countries ${ }^{[5,6,7]}$. Blindness is one of the most feared complication of diabetes mellitus but also one of the most preventable. Diabetes mellitus is the commonest cause of blindness in people aged 30-69 years. Twenty years after the onset of diabetes mellitus, almost all patients with type 1 diabetes mellitus and over $60 \%$ of patients with type 2 diabetes mellitus will have some degree of retinopathy ${ }^{[8,9]}$. Vision threatening retinopathy is rare in type 1 diabetes mellitus in the first 3-5 years of diabetes mellitus or before puberty ${ }^{[9]}$. Even at the time of diagnosis of type 2 diabetes mellitus, about a quarter of patients have established background retinopathy ${ }^{[8]}$. The World Health Organization (WHO) lists diabetic retinopathy as a priority disease in their "VISION 2020" program initiative for the global elimination of avoidable blindness ${ }^{[10,11]}$. It is estimated that the global magnitude of diabetic retinopathy will increase from 126.6 million in 2010 to 191 million by 2030. Present review shows that prevalence of diabetic retinopathy in India and China is significantly lower ${ }^{[12]}$. The reported prevalence of diabetic retinopathy in India ranges from $17.6 \%$ to $28.2 \%{ }^{[13]}$. 


\section{Methodology}

Study design: Cross sectional study

Study setting: Kanyakumari district. Kanyakumari is the southernmost district of Tamilnadu, with the second largest density in the state. The district is divided into 4 taluks and 9 blocks.

Approximate total duration of the study: 3 months.

Detailed description of the groups: Type 2 diabetes mellitus patient of age more than $40 \mathrm{yrs}$, duration more than 5 years.

Sample size of the study: 85 .

Sampling technique used in the study: Convenient sampling technique is used.

\section{Inclusion criteria}

Type 2 diabetes mellitus patient for a minimum duration of 5 years Age group of more than 40 years.

Either sex.

\section{Exclusion criteria}

Subjects in whom dilatation of pupils was contraindicated, e.g. angle closure glaucoma, anterior chamber intraocular lens implant.

Subjects with hazy media, e.g. corneal opacities, healed or active anterior uveitis, cataract, vitreous opacities.

Subject with gestational diabetes.

Parameters to be studied: Age, sex, duration of diabetes.

\section{Results}

In this study the prevalence of patient with diabetic retinopathy was $55.30 \%$ and without diabetic retinopathy was $44.70 \%$. Mean age for development of diabetic retinopathy was 61.85 years. Diabetic retinopathy among male $(57.45 \%)$ was more than in female $(42.55 \%)$. Mean duration for development of diabetic retinopathy was 12.12 yrs.

Table 1: Distribution of type-2 diabetes mellitus patients based on diabetic retinopathy

\begin{tabular}{|c|c|c|}
\hline Patients & Number & Percentage (\%) \\
\hline Patients with diabetic retinopathy & 47 & 55.30 \\
\hline Patients without diabetic retinopathy & 38 & 44.70 \\
\hline
\end{tabular}

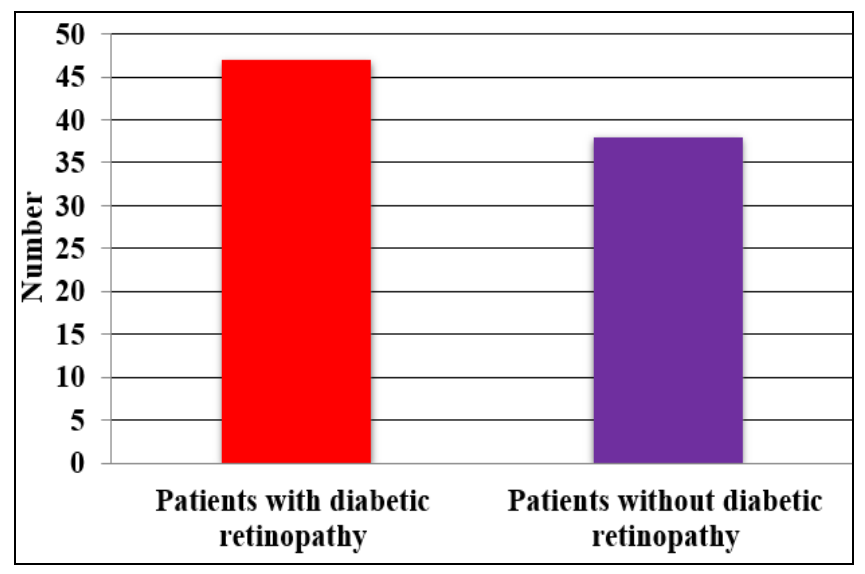

Graph 1: Distribution of type-2 diabetes mellitus patients based on diabetic retinopathy

In this study the prevalence of patient with diabetic retinopathy was $55.30 \%$ and without diabetic retinopathy was $44.70 \%$.
Table 2: Distribution of diabetic retinopathy patients based on the age

\begin{tabular}{|c|c|c|}
\hline Age (Years) & Number & Percentage (\%) \\
\hline $45-50 \mathrm{Y}$ & 4 & 8.51 \\
\hline $51-55 \mathrm{Y}$ & 9 & 19.15 \\
\hline $56-60 \mathrm{Y}$ & 10 & 21.28 \\
\hline $61-65 \mathrm{Y}$ & 8 & 17.02 \\
\hline $66-70 \mathrm{Y}$ & 11 & 23.40 \\
\hline $71-75 \mathrm{Y}$ & 3 & 6.38 \\
\hline $76-80 \mathrm{Y}$ & 2 & 4.26 \\
\hline
\end{tabular}

In this study mean age for development of diabetic retinopathy was 61.85 yrs. Graph-2: Distribution of diabetic retinopathy patients based on the age

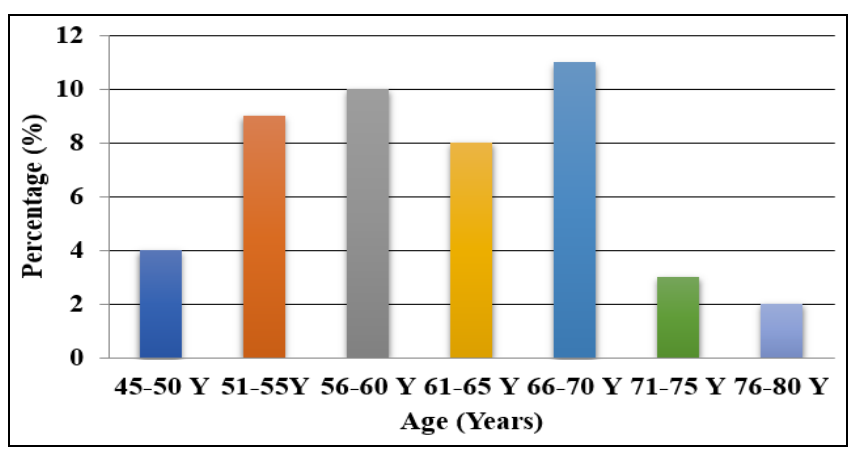

Graph 2: Distribution of diabetic retinopathy patients based on the age

Table 3: Distribution of diabetic retinopathy patients based on the gender

\begin{tabular}{|c|c|c|}
\hline Gender & Number & Percentage (\%) \\
\hline Male & 27 & 57.45 \\
\hline Female & 20 & 42.55 \\
\hline
\end{tabular}

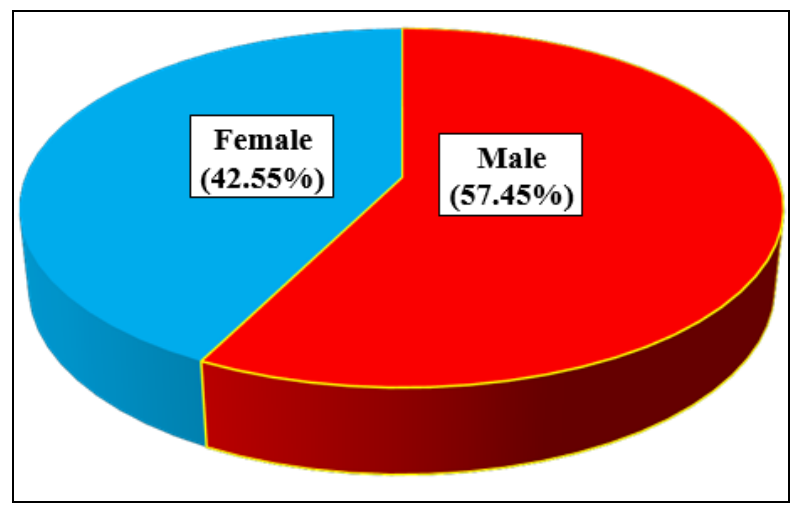

Graph 3: Distribution of diabetic retinopathy patients based on the gender

In this study diabetic retinopathy among male was more than in female.

Table 4: Distribution of diabetic retinopathy patients based on the duration of diabetes

\begin{tabular}{|c|c|c|}
\hline Duration of diabetes (Y) & Number & Percentage (\%) \\
\hline $5-10 \mathrm{Y}$ & 24 & 51.06 \\
\hline $11-15 \mathrm{Y}$ & 12 & 25.53 \\
\hline $16-20 \mathrm{Y}$ & 9 & 19.15 \\
\hline $21-26 \mathrm{Y}$ & 0 & 0.00 \\
\hline $27-30 \mathrm{Y}$ & 1 & 2.13 \\
\hline $31-35 \mathrm{Y}$ & 1 & 2.13 \\
\hline
\end{tabular}




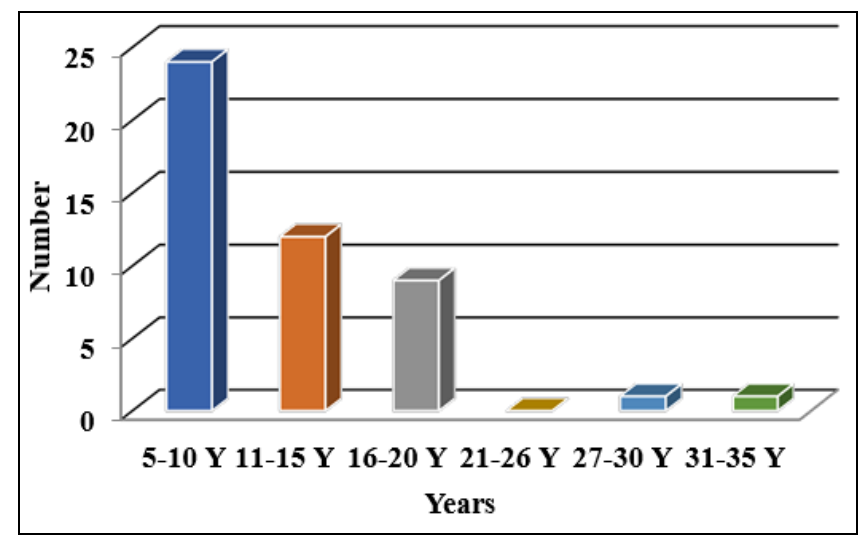

Graph 4: Distribution of diabetic retinopathy patients based on the duration of diabetes

In this study mean duration for development of diabetic retinopathy was 12.12 yrs.

\section{Discussion}

A cross sectional study was conducted among 85 type 2 diabetes mellitus patient attending ophthalmology OPD in Sree Mookambiga Institute of Medical Sciences In my study conducted among 85 T2DM patients, 47 patients $(55.30 \%)$ had diabetic retinopathy.

Fong DS et al. in 2003 states Diabetic retinopathy is the most frequent cause of new cases of blindness among adults aged 20-74 years. During the first two decades of disease, nearly all patients with type 1 diabetes and $>60 \%$ of patients with type 2 diabetes have retinopathy ${ }^{[9]}$.

Ruta LM et al, 2013 A total of 72 articles from 33 countries were included Prevalence estimates varied from as low as $10 \%$ to as high as $61 \%$ in persons with known diabetes Prevalence of diabetic retinopathy was higher in developing countries ${ }^{[14]}$.

Wisconsin Epidemiological Study for Diabetic Retinopathy conducted in the USA among 1313 subjects where 50.3\% had diabetic retinopathy. However WESDR study was conducted among type I diabetics ${ }^{[15]}$.

In this study mean age of diabetic retinopathy patients was 61.85 yrs. There was a significant association between increasing age and diabetic retinopathy (p- value 0.001). Van Leiden et al studied relationship of diabetic retinopathy with various risk factors in 233 individuals. His study gives $\mathrm{P}$-value of $<0.03$ when diabetic retinopathy was correlated with age of patient ${ }^{[16]}$.

In my study mean duration of diabetes mellitus for development of diabetic retinopathy was 12.12 yrs. My study shows there is an association between duration of diabetic retinopathy and duration of T2DM. ( $p$ - Value $0.0001)$ In my study diabetic retinopathy was observed more in male $(57.45 \%)$ when compared with female $(42.55 \%)$.

Yin L et al in 2020, Diabetic retinopathic patients were likely to be elder $(\mathrm{P}=.0003)$, men $(\mathrm{P}=.018)$, hypertensive $(P<.0001)$, and had high body mass index $(P<.0001)$, metabolic abnormalities, and longer duration of diabetes $(P<.0001)$. Higher intraocular pressure $(\mathrm{P}=.0008)$, fasting blood glucose $(P<$. 0001), serum total cholesterol $(P<$. 0001), serum triglyceride $(\mathrm{P}=.0006)$, \% glycated hemoglobin (HbA1c) $(P<.0001)$, and disc asymmetry including cup-disc ratio $(\mathrm{P}=.041)$ reported in patients with diabetic retinopathy. Age $(\mathrm{P}=$. 049), male sex $(\mathrm{P}=)$, hypertension $(\mathrm{P}=.048)$, duration of diabetes $(\mathrm{P}=.012)$, diabetic neuropathy $(\mathrm{P}=.048)$, diabetic nephropathy $(\mathrm{P}=$. 048), diabetic foot ulcer ( $\mathrm{P}=.041)$, foot amputation ( $\mathrm{P}=$. 042), fasting blood glucose $(\mathrm{P}=.022)$, serum total cholesterol $(\mathrm{P}=.028)$, serum triglyceride $(\mathrm{P}=.035)$, and HbA1c $(\mathrm{P}=.042)$ were associated with diabetic retinopathy [17].

\section{Conclusion}

This study estimated the prevalence of Diabetic retinopathy to be $55.30 \%$ among type 2 diabetes mellitus patients of age more than 40years and duration of diabetes mellitus more than 5 years in Kulesekharam, Kanyakumari, Hospital based type 2 diabetic population attending ophthalmology out patient department sree mookambiga institute of medical sciences. Our study also created awareness among the patients who participated about diabetic retinopathy and its effect on eye.

Funds: Self.

\section{Conflict of interest: None.}

\section{References}

1. Cho NH, Shaw JE, Karuranga S, Huang Y, da Rocha Fernandes JD, Ohlrogge AW, et al. IDF Diabetes Atlas: Global estimates of diabetes prevalence for 2017 and projections for 2045. Diabetes Res Clin Pract 2018;138:271-281

2. International Diabetes Federation (IDF). IDF Diabetes Atlas. 7th ed. 2015. Available from: http://www.idf.org/idf-diabetes-atlas-seventh-edition.

3. Zheng $\mathrm{Y}$, Ley $\mathrm{SH}, \mathrm{Hu}$ FB. Global aetiology and epidemiology of type 2 diabetes mellitus and its complications. Nat Rev Endocrinol 2018;14(2):88-98.

4. Gadkari SS, Maskati QB, Nayak BK. Prevalence of diabetic retinopathy in India: The All India Ophthalmological Society Diabetic Retinopathy Eye Screening Study 2014. Indian J Ophthalmol 2016;64(1):38-44

5. Aiello LM. Perspectives on diabetic retinopathy. Am J Ophthalmol 2003;136(1):122-35.

6. Porta M, Bandello F. Diabetic retinopathy: A clinical update. Diabetologia 2002;45(12):1617-34.

7. Das A. Diabetic retinopathy: Battling the global epidemic. Indian J Ophthalmol 2016;64(1):2-3.

8. Watkins PJ. ABC of diabetes retinopathy. BMJ 2003;326:924-6.

9. Fong DS, Aiello L, Gardner TW, King GL, Blankenship G, Cavallerno JD, et al. Diabetic retinopathy. Diabetic Care 2003;26(Suppl-1):S99-102.

10. World Health Organization, Global Initiative for the Elimination of Avoidable Blindness.

11. Geneva, Switzerland World Health Organization 1997.

12. Resnikoff, Spararajasegaram R. Blindness prevention programs: past, present and future. Bull World Health Organ 2001;79222-226.

13. Murthy GV, Das T. Diabetic care initiatives to prevent blindness from diabetic retinopathy in India. Indian $\mathbf{J}$ Ophthalmol 2016;64(1):50-4.

14. Aurora DT, Chhablani J, Giridhar A, Kumar A, Raman $\mathrm{R}$, et al. Evidence based review of diabetic macular oedema management. Consensus statement on Indian 
treatment guidelines.Indian J Ophthalmol 2016;64:1425.

15. Ruta LM, Magliano DJ, Lemesurier R, Taylor HR, Zimmet PZ, Shaw JE, et al. Prevalence of diabetic retinopathy in Type 2 diabetes in developing and developed countries. Diabet Med 2013;30(4):387-98.

16. Klein R, Klein BE, Moss SE, Cruickshanks KJ. The Wisconsin Epidemiologic Study of Diabetic Retinopathy: XVII. The 14-year incidence and progression of diabetic retinopathy and associated risk factors in type 1 diabetes. Ophthalmology 1998;105(10):1801-15.

17. Van Leiden H, Dekker JM, Moll AC, et al. Risk factors for incident retinopathy in a diabetic and nondiabetic population: The Hoorn Study. Arch Ophthalmol 2003;121:245.

18. Yin L, Zhang D, Ren Q, Su X, Sun Z. Prevalence and risk factors of diabetic retinopathy in diabetic patients: A community based cross-sectional study. Medicine (Baltimore) 2020;99(9):e19236. 